\title{
Experimental Research on the Qualitative Characteristics of Iron Ores and Ferrous Waste That Can Be Used in Blast Furnace Mixt Injection Technology
}

\begin{abstract}
MIHAI DUMITRU TUDOR ${ }^{1}$, MIRCEA HRITAC ${ }^{2}$, NICOLAE CONSTANTIN ${ }^{2}$, MIHAI BUTU' ${ }^{1}$, VALERIU RUCAI ${ }^{1}$, CRISTIAN DO BRESCU ${ }^{1}$
'Politehnica University of Bucharest, 313 Splaiul Independentei, 060042, Bucharest, Romania

2SC CERMAX 2000 PATENTS SRL, 26 Prevederii Str., 032304, Bucharest, Romania

Direct use of iron ores in blast furnaces, without prior sintering leads to a reduction in production costs and energy consumption [1,2]. Fine-grained iron ores and iron oxides from ferrous wastes can be used together with coal dust and limestone in mixed injection technology through the furnace tuyeres. In this paper are presented the results of experimental laboratory investigations for establishing the physic-chemical characteristics of fine materials (iron ore, limestone, pulverized coal) susceptible to be used for mixed injection in blast furnace. [1,4]. The results of the experimental research have shown that all the raw materials analyzed can be used for mixt injection in blast furnace.
\end{abstract}

Keywords: iron ores, reducibility, mixt injection, blast furnaces, pulverized coal, ferrous wastes.

Mixed injection technology into blast furnace of iron ores together with limestone and pulverized coal represents a problem with the approach and relatively recent debate worldwide $[1,2,6]$.

This would allow recycling of ferrous wastes generated in iron and steel making industry (blast furnace dust, blast furnace sludge, dross, steel slag, rolling mill) by direct injection into the blast furnace.

The use of these ferrous wastes, very low-grain iron ores, coal dust, is done with very little pre-treatment operations [3].

The advantages of applying this technology are as follows:

- production of an extra quantity of pig iron directly into the furnace crucible by reducing the iron oxides introduced through the tuyeres [2];

- reducing the specific consumption of coke, because the reduction of the iron oxides introduced into the tuyeres is made with carbon from pulverized coal;

- increasing the amount of heat in the blast furnace crucible by burning the additional carbon from the pulverized coal $[4,5]$;

- improving the quality of pig iron, mainly by increasing the $\mathrm{Si}$ content, which produces a reduction in production costs in the steel industry by $0.3 \ldots 0.5 \%$ / t for each $0.1 \% \mathrm{Si}$ added in pig iron $[4,8]$;

- improving the value of the coke replacement ratio by pulverized coal and increasing the amount of pulverized coal injected into the blast furnace.

This would implicitly to the reduction of the polluting effect of iron and steel on the environment $[5,9]$.

From an ecological point of view, the development of a mixt injection furnace technology is also very important [10].

This would allow the recycling of ferrous wastes obtaining in the iron and steel industry (blast furnace dust, steel dust, blast furnace sludge, rolling mill, etc.) by direct blowing into the furnace without being processed in the agglomeration process $[2,3,7]$.

\section{Experimental part}

Determining the chemical composition

The chemical composition of the materials together with the rheological characterization represents the main criterion of choice for use in blast furnace mixt injection.

For determining the presence of the main constituent elements and share of the accompanying elements a qualitative and semi-quantitative spectral analysis was performed.

The analyzed materials can be classified after of iron content in:

- very rich (63-66\% Fe): Brazil iron ore, South Africa iron ore, Venezuela iron ore and Krivoi Rog iron ore concentrate; - rich (60-63\% Fe): Australian BHP ore, ore from India;

- medium (under 60\% Fe): Australian Robe River iron ore.

All materials are relatively low $\mathrm{SiO}_{2}$ content, except Krivoi Rog iron ore concentrate $\left(9.84 \% \mathrm{SiO}_{2}\right)$.

All materials have acceptable contents of harmful elements ( $\mathrm{S}, \mathrm{P}, \mathrm{Na}, \mathrm{K}, \mathrm{Pb}, \mathrm{Zn}, \mathrm{Cu})$ and negligible accompanying elements ( $\mathrm{V}, \mathrm{Co}, \mathrm{Ni}, \mathrm{Cr}$, etc.).

The Robe River iron ore has the disadvantage of having a high content of crystallization water, whose dissociation in hydrates consumes an additional heat in the blast furnace.

The chemical composition of the materials is presented in Table 1.

\section{Determining granulometric composition}

For granulometric analysis, the material is successively ranked on a series of sites (sieve surfaces), starting with the one with the largest mesh surface and ending with the one with the smallest mesh surface. The material remaining on each screen area and the one passed through the site are granulometric classes.

By granulometric class is meant the proportion of granules of size between certain limits and expressed by percentage. Each granulometric class has the size of the eye of the last site through which the material and size of the last site of the material remained. 
All materials have been subject of the dry granulometric analysis on the $0.063-10 \mathrm{~mm}$ sieves.

Since much of the fine and ultrafine fractions contain materials $(-0.063 \mathrm{~mm})$ with weights ranging from $0.112 \%$ (South Africa) to $9.68 \%$ (Brazil) we proceeded with the wet gravitational analysis to determine values for fractions: $-0.01 \mathrm{~mm}, 0.01-0.025 \mathrm{~mm}, 0.025-0.04 \mathrm{~mm}$ and 0.04 $0.063 \mathrm{~mm}$.

The results of these determinations are presented in Table 2.

For some materials with higher weights of ultrafine fractions we proceeded, in addition, at an optical particle size analysis of fractions smaller than $0.01 \mathrm{~mm}$.

Analysing these data, we can see the broad spectrum of these materials granulations from fine and ultrafine material category (the iron ore concentrate) to the higher average sized materials such as South Africa, Venezuela and BHP (Australia) iron ore.

\section{Determining the rheological characteristics}

Rheological characteristics (flow) of the material have been studied to obtain data necessary for the design of injection installation, for pneumatic transport of materials and for choosing the most suitable sorts of iron ores for mixt injection technology.

The results obtained are presented in Table 3.

The best rheological characteristics (for ferrous materials) are for:

- iron ore from India: $72.12 \mathrm{~g} / \mathrm{cm}^{2} . \mathrm{s}$ flow rate and 35.69 $\mathrm{cm} / \mathrm{s}$ velocity;

- iron ore concentrate Krivoi Rog: $70.63 \mathrm{~g} / \mathrm{cm}^{2} \cdot \mathrm{s}$ flow rate and $37.17 \mathrm{~cm} / \mathrm{s}$ velocity.

Lowest results for:

- iron ore from South Africa: $62.63 \mathrm{~g} / \mathrm{cm}^{2} .5$ flow rate and $28.47 \mathrm{~cm} / \mathrm{s}$ velocity;

- iron ore BHP: $65.22 \mathrm{~g} / \mathrm{cm}^{2} . \mathrm{s}$ flow rate and $31.77 \mathrm{~cm} / \mathrm{s}$ velocity.

These values were determined for fine fractions $1<1$ $\mathrm{mm})$, dried at $0 \%$ moisture.

For a $3 \%$ humidity in iron ore, flow characteristics worsen by $5-10 \%$ and at $5 \%$ humidity in iron ore, rheological characteristics are minimal.

It is widely accepted that to be used in injecting mixed, ore, limestone and coal must be less than $0.1 \mathrm{~mm}$ grain. This dimension that can be obtained only by grinding them [5].

It should be kept in mind that the energy required for crushing increases exponentially with increasing milling degree.

If for coal and limestone there is no alternative, for iron ore is preferred an average particle size diameter as low as possible.

From this point of view, as shown, that the most advantageous in this case are:

- Krivoi Rog iron ore concentrate: $0.15 \mathrm{~mm}$, medium diameter, $57.45 \%$ smaller than $0.1 \mathrm{~mm}$;

- India iron ore: $2.75 \mathrm{~mm}$, medium diameter, $15.19 \%$ smaller than $0.1 \mathrm{~mm}$;

- Australian Robe River iron ore: 3.09 mm, medium diameter, $12.58 \%$ smaller than $0.1 \mathrm{~mm}$;

- Brazil iron ore: $1.92 \mathrm{~mm}$, medium diameter, $10.76 \%$ smaller than $0.1 \mathrm{~mm}$.

\section{Determining the behaviour at humectation}

All materials must be dried beneath $1 \%$ humidity, before being grinded under $0.1 \mathrm{~mm}$, transported and injected in the furnace.

So, it's necessary to know the natural humectation tendency, while depositing the materials, as well capacity of absorbing the air humidity, after drying, of all studied materials.

The humectation behaviour was determined with a device, which measures the time and the water quantity absorbed, through capillary pressure for each material.

The measurement results were statistically presented as averages, after three determination for each. The absorption time and the speed have different values for each material.

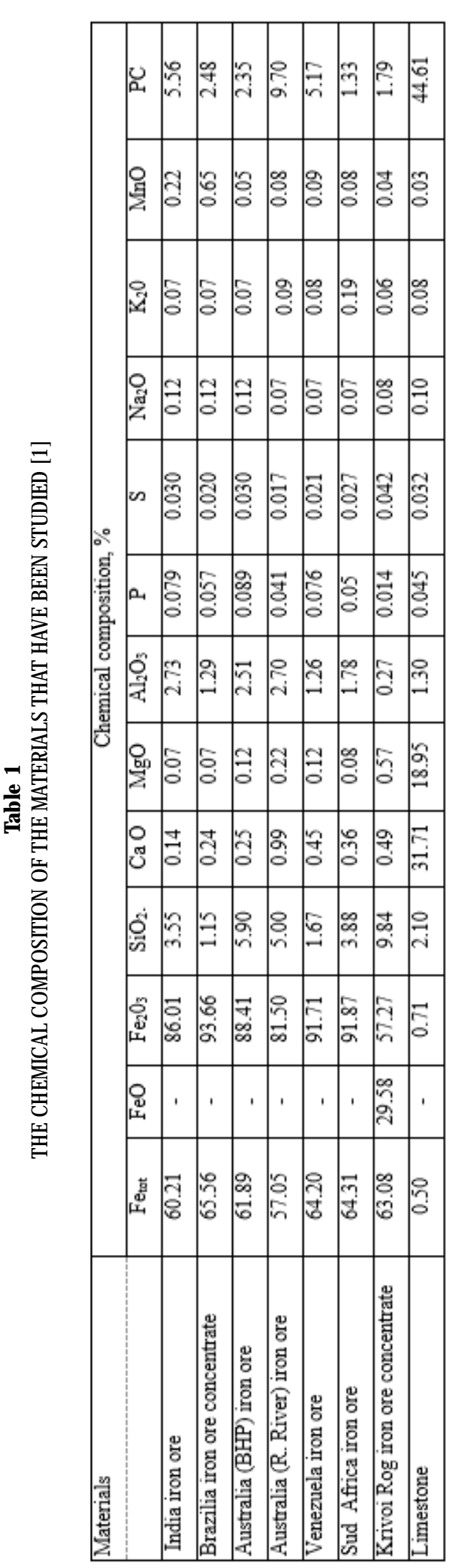



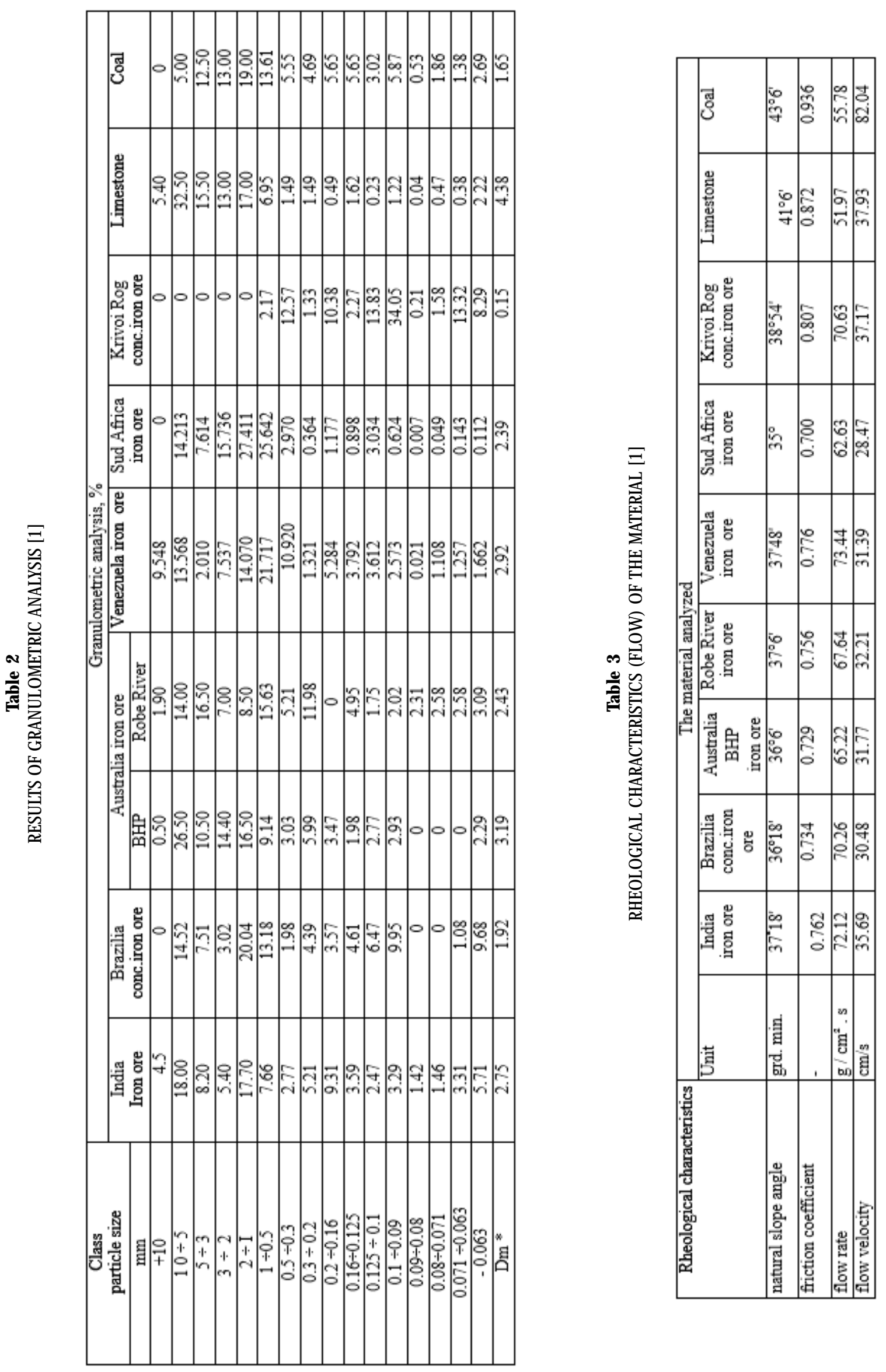

From all iron ore, the ore from India $\left(0.2356 \mathrm{~cm}^{3} / \mathrm{s}\right)$ has the smallest humectation capacity, followed by the iron ore concentrate from Brazil and the iron ore from Australia $\operatorname{BHP}\left(0.2362 \mathrm{~cm}^{3} / \mathrm{s}\right)$ and the highest the iron ore from Venezuela $\left(0.2791 \mathrm{~cm}^{3} / \mathrm{s}\right)$.

\section{Determining the volumetric mass}

Determining the volumetric mass for the studied materials was done for the initial granulation $(0-10 \mathrm{~mm})$, as well as for the granulometric fractions separated by the category's large granulation fractions (>2 $\mathrm{mm}$ ), fine fractions $(0.5-2 \mathrm{~mm})$ and ultrafine fractions $(<0.5 \mathrm{~mm})$. The results are presented in Table 4. 


\begin{tabular}{|l|c|c|c|c|}
\hline \multirow{2}{*}{ Material } & \multicolumn{4}{|c|}{ Granulometric fraction, mm } \\
\cline { 2 - 5 } & +2 & $0,5 \div 2$ & -0.5 & $0 \div 10$ \\
\hline India iron ore & 1.74 & 1.66 & 1.78 & 2.05 \\
\hline Brazil iron ore concentrate & 2.16 & 2.15 & 2.26 & 2.49 \\
\hline Australia BHP iron ore & 1.96 & 1.98 & 2.03 & 2.21 \\
\hline Australia Robe River ore & 1.96 & 1.92 & 1.81 & 2.10 \\
\hline Venezuela iron ore & 2.00 & 1.88 & 2.02 & 2.34 \\
\hline South Africa iron ore & 2.47 & 2.51 & 2.19 & 2.81 \\
\hline Krivoi Rog iron ore concentrate & 1,92 & 1.83 & 1.60 & 2.05 \\
\hline Limestone & 1.46 & 1.47 & 1.48 & 1.57 \\
\hline Coal & 0.66 & 0.71 & 0.68 & 0.96 \\
\hline
\end{tabular}

Table 4

VOLUMETRIC MASS (BULK) OF MATERIALS, $\mathrm{g} / \mathrm{cm}^{3}[1]$
The value hierarchy (ore from South Africa, maximum volumetric mass, ore from India, minimum volumetric mass) is maintained for every granulometric fraction.

For all the materials examined were determined: the angle of the natural slope, the coefficient of friction, the flow rate, $\mathrm{g} / \mathrm{cm}^{2} \mathrm{~s}$ and flow velocity, $\mathrm{cm} / \mathrm{s}$.

\section{Determining the iron ore reductibility}

A basic property of iron ore capacity to reduce them is expressed by the degree of reduction. It is the ratio of the amount of oxygen eliminated in an interval of time up to a certain temperature and total amount of oxygen present in the sample $[1,2,6]$.

Reactions between iron oxides and carbon oxide or hydrogen to obtain iron together with the expressions for calculation of the principal thermodynamic parameters of these reactions, free energy Gibbs $\left(\ddot{A}^{\circ}{ }_{T}\right)$ and the logarithm of the equilibrium constant $(\lg K)$ are shown in Table 5 .

Using the software HSC Chemistry 6.0, the free enthalpies were determined for the main reactions that can occur - (1) $\div$ (8).

Under standard temperature and pressure conditions, the values of DG, presented in Table 6, calculated with HSC Chemistry 6.0, for reactions (3), (4), (7) and (8) are positive (Figure 1).

This would mean that the fresh iron reduced with $\mathrm{CO}_{2}$, respectively $\mathrm{H}_{2}$, would oxidize in the presence of $\mathrm{CO}_{2}$ or $\mathrm{H}_{2} \mathrm{O}$ of the gas existing at that level in the furnace tank.
Taking into account the kinetics of the reductionoxidation processes dictated by the counter-current circulation of the phases in the furnace, the gas phase with pressure greater than $1 \mathrm{~atm}$. Quickly leaves the reaction zone going to the furnace mouth, the iron fraction that can oxidize is reduced again, so that the result of reactions (1) $\div(4)$, respectively $(5) \div(8)$, is the obtaining of metallic iron.

From this table, it can be seen that the reductibility of iron oxide can be investigated experimentally using hydrogen as a reducing agent.

Laboratory installation for determining the iron ore reductibility is presented in Figure 2 .

The determination is made in a reactor tube (1) with an inside diameter of $140 \mathrm{~mm}$ and length of $1000 \mathrm{~mm}$ made of stainless steel, which has the bottom filled with chamotte balls (2) for preheating the reducing gas.

The ore or agglomerate sample is placed in a cylindrical retort (3) sized to receive quantities of 1 to $3 \mathrm{~kg}$. Reactor tube heating is done in a tubular furnace with silicon carbide bars (4) which can provide temperatures in the order of $800-1000^{\circ} \mathrm{C}$ (furnace power is $25 \mathrm{KVA}$ ).

The reducing gas is hydrogen with $99.5 \%$ purity. This gas provides from the tubular hydrogen tank (5). The gas is first passed through purification recipients filled with glass wool (6), sulfuric acid (7) and calcium chloride (8). The hydrogen flow is measured and recorded using a rotameter (9) and a gas meter (10).

\begin{tabular}{|l|l|l|l|}
\hline & Reaction & $\Delta \mathrm{G}^{0} \mathrm{~T}, \mathrm{~J} / \mathrm{mol}$ & $l \mathrm{lg} \mathrm{K}$ \\
\hline $\mathrm{t} \geq 572^{\circ} \mathrm{C}$ & $3 \mathrm{Fe}_{2} \mathrm{O}_{3}+\mathrm{CO}=2 \mathrm{Fe}_{3} \mathrm{O}_{4}+\mathrm{CO}_{2}$ & $-39762^{8} 53.61 \mathrm{~T}$ & $2076 / \mathrm{T}+2.8$ \\
\cline { 2 - 4 } & $\mathrm{Fe}_{3} \mathrm{O}_{4}+\mathrm{CO}=3 \mathrm{FeO}+\mathrm{CO}_{2}$ & $+35472^{*} 40.20 \mathrm{~T}$ & $-1850 / \mathrm{T}+2.1$ \\
\cline { 2 - 4 } & $\mathrm{FeO}+\mathrm{CO}=\mathrm{Fe}+\mathrm{CO}_{2}$ & $+13175+17.23 \mathrm{~T}$ & $688 / \mathrm{T}-0.9$ \\
\hline $\mathrm{t} \leq 572^{\circ} \mathrm{C}$ & $1 / 4 \mathrm{Fe}_{3} \mathrm{O}_{4}+\mathrm{CO}=3 / 4 \mathrm{Fe} \mathrm{CO}_{2}$ & $-1034+2.87 \mathrm{~T}$ & $54 / \mathrm{T}-0.15$ \\
\hline $\mathrm{t} \geq 572^{\circ} \mathrm{C}$ & $3 \mathrm{Fe}_{2} \mathrm{O}_{3}+\mathrm{H}_{2}=2 \mathrm{Fe}_{3} \mathrm{O}_{4}+\mathrm{H}_{2} \mathrm{O}$ & $-9268-82.03 \mathrm{~T}$ & $484 / \mathrm{T}+4.28$ \\
\cline { 2 - 5 } & $\mathrm{Fe}_{3} \mathrm{O}_{4}+\mathrm{H}_{2}=3 \mathrm{FeO}+\mathrm{H}_{2} \mathrm{O}$ & $+65920-68.31 \mathrm{~T}$ & $-3442 / \mathrm{T}+3.57$ \\
\cline { 2 - 5 } & $\mathrm{FeO}+\mathrm{H}_{2}=\mathrm{Fe}+\mathrm{H}_{2} \mathrm{O}$ & $+17318-10.88 \mathrm{~T}$ & $-904 / \mathrm{T}+3.57$ \\
\hline $\mathrm{t} \leq 572^{\circ} \mathrm{C}$ & $1 / 4 \mathrm{Fe}_{3} \mathrm{O}_{4}+\mathrm{H}_{2}=3 / 4 \mathrm{Fe}+\mathrm{H}_{2} \mathrm{O}$ & $+29459-25.25 \mathrm{~T}$ & $-1538 / \mathrm{T}+1.32$ \\
\hline
\end{tabular}

Table 5

REACTIONS TO REDUCE IRON OXIDE [2]
Fig. 1. Variation of standard free enthalpy $(\Delta \mathrm{G})$ in the temperature range $800-1000^{\circ} \mathrm{C}$ for the reactions studied 
Table 6

GIBBS ENERGY VARIATIONS FOR REACTIONS (1) $\div$ (8)

\begin{tabular}{|c|c|c|c|c|c|c|c|c|}
\hline $\begin{array}{c}\text { Temperature, } \\
{ }^{\circ} \mathrm{C}\end{array}$ & \multicolumn{9}{|c|}{$\Delta \mathrm{G}(\mathrm{kcal})$} \\
\cline { 2 - 9 } & $\Delta \mathrm{G} 1$ & $\Delta \mathrm{G} 2$ & $\Delta \mathrm{G} 3$ & $\Delta \mathrm{G} 4$ & $\Delta \mathrm{G} 5$ & $\Delta \mathrm{G} 6$ & $\Delta \mathrm{G} 7$ & $\Delta \mathrm{G} 8$ \\
\hline 800.000 & -24.281 & -0.967 & 1.208 & 0.664 & -24.158 & -0.844 & 1.331 & 0.787 \\
\hline 820.000 & -24.577 & -1.028 & 1.305 & 0.722 & -24.604 & -1.055 & 1.279 & 0.695 \\
\hline 840.000 & -24.874 & -1.090 & 1.402 & 0.779 & -25.048 & -1.264 & 1.227 & 0.604 \\
\hline 860.000 & -25.170 & -1.151 & 1.498 & 0.835 & -25.492 & -1.474 & 1.176 & 0.513 \\
\hline 880.000 & -25.466 & -1.214 & 1.593 & 0.892 & -25.935 & -1.682 & 1.125 & 0.423 \\
\hline 900.000 & -25.762 & -1.276 & 1.689 & 0.947 & -26.377 & -1.891 & 1.074 & 0.333 \\
\hline 920.000 & -26.057 & -1.339 & 1.782 & 1.002 & -26.817 & -2.099 & 1.022 & 0.242 \\
\hline 940.000 & -26.352 & -1.403 & 1.873 & 1.054 & -27.256 & -2.307 & 0.969 & 0.150 \\
\hline 960.000 & -26.645 & -1.468 & 1.965 & 1.107 & -27.693 & -2.516 & 0.917 & 0.059 \\
\hline 980.000 & -26.938 & -1.534 & 2.057 & 1.159 & -28.129 & -2.724 & 0.867 & -0.031 \\
\hline 1000.000 & -27.230 & -1.600 & 2.149 & 1.212 & -28.563 & -2.933 & 0.817 & -0.121 \\
\hline
\end{tabular}

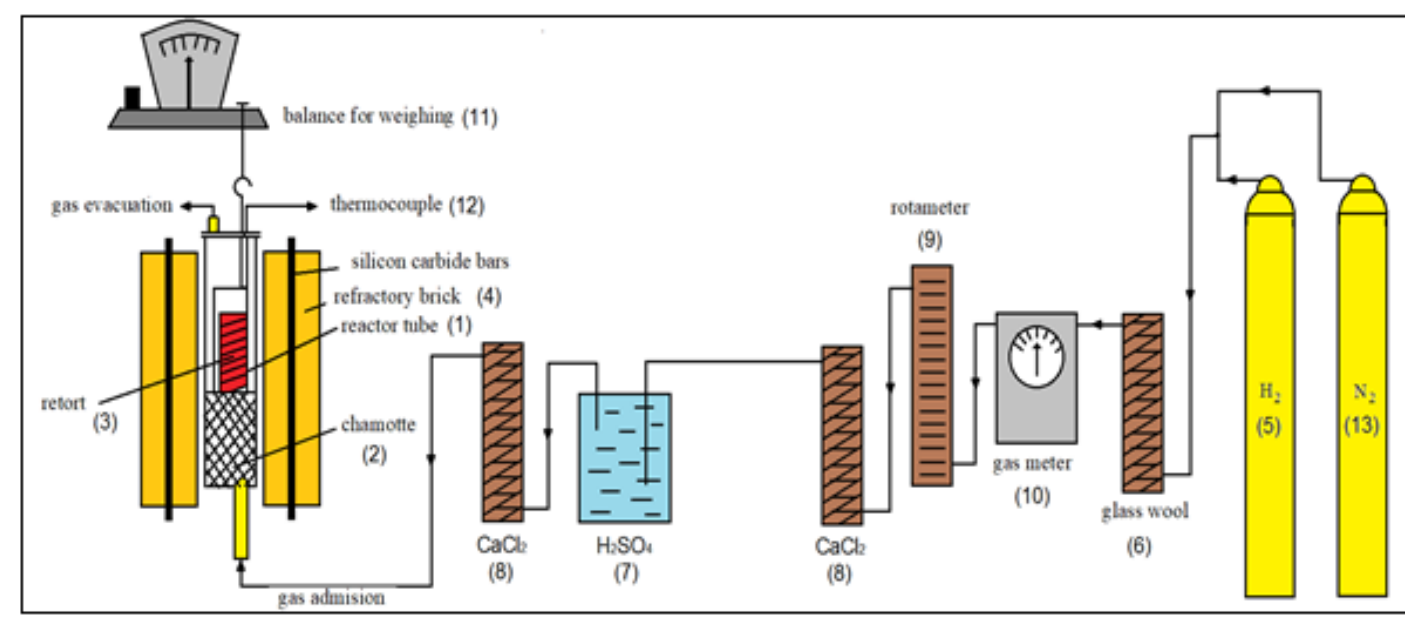

Fig. 2. Schematic of the laboratory installation for determining the reductibility $[1,8]$

\begin{tabular}{|l|c|}
\hline \multicolumn{1}{|c|}{ Ore } & GR - Reductibility, $\%$ \\
\hline India iron ore & 80.19 \\
\hline Brazil iron ore concentrate & 74.93 \\
\hline Australia BHP iron ore & 75.49 \\
\hline Australia Robe River iron ore & 79.91 \\
\hline Venezuela iron ore & 78.12 \\
\hline South Africa iron ore & 75.20 \\
\hline Krivoi Rog iron ore concentrate & 73.32 \\
\hline
\end{tabular}

Table 7

THE RESULTS OF DETERMINATION OF THE ANALYZED MATERIALS REDUCTIBILITY [1]

The values represent an average of three determinations, $\varepsilon=1 \%$

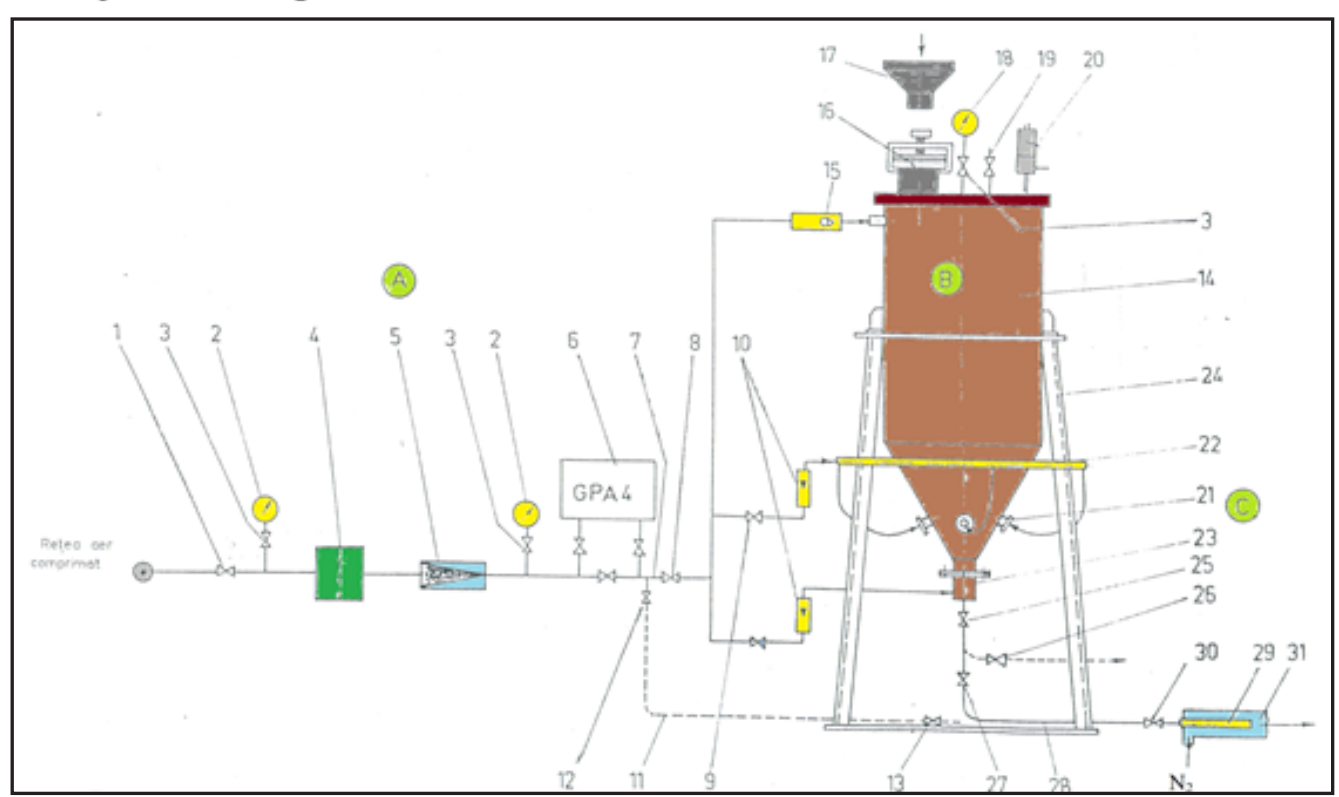

Fig. 3. Schematic of the experimental installation for introducing dust into the blast furnace [1]: 1. valve; 2. manometer; 3. valve 1/2"; 4. air filter; 5. pressure reducer; 6. molecular sieve air dryer; 7. air duct; 8. spherical valve 1"; 9. spherical valve 1"; 10. pipe air; 11. valve 1/2"; 12. spherical valve 1/2"; 13. Rotomer Rotrom - 1 - 25; 14. powder distributor; 15. sense valve; 16. Quick-closing power supply device; 17. food funnel; 18. indicator gauge è $160 \mathrm{~mm}$; 19 . connection with 1/2" ball valve; 20 . DN 25/40 water safety valve; 21 . insufflation nozzle;

22. air distribution duct; 23 . dosing and fluidization device; 24. carrier; 25 . inch ball valve 1/2"; 26. 1/2" spigot connection;

27. valve with 1/2" sphere; 28 . transport pipeline; 29. pipe mixing mixture; 30. 1/2" spigot valve; 31. mixed powder injection lance 
Determining the amount of oxygen eliminated during the reduction is done by continuously weighing the reactor tube in which the sample is located, by means of the balance (11).

With a Pt-Pt-Rh thermocouple (12) introduced into the sample is measuring the temperature.

The cylindrical retort (3) is held for one hour in a calcining furnace to dry the sample at approximately $110^{\circ} \mathrm{C}$, after which it is introduced into the reactor tube. When the temperature reaches $800-1000^{\circ} \mathrm{C}$, is blow the gas. At first, the sample is purged for approx. 5 minutes with nitrogen from the cylinder (13).

The introduction of hydrogen is made with a specific flow rate of $0.07 \mathrm{I} \mathrm{H}_{2} / \mathrm{gO}_{2}$ initially in the sample. The blow time is 45 minutes. Variation of sample weight during $\mathrm{H}_{2}$ blowing is signalled by the balance.

Once again, nitrogen is poured over the sample and then cooled with the oven for $24 \mathrm{~h}$.

The sample is drawn from the tube and is weigh the material from the cylindrical retort. The reduction of iron ore is expressed by the indicator (GR -reduction degree), which represents the percentage of the amount of oxygen removed by reduction (weight loss of the sample) and the amount of oxygen initially present in the sample $[1,2,6]$.

Measurements made in accordance with international standards are shown in Table 6.

The experimental results confirm that the value of the degree of reducibility is mainly influenced by the structure and mineralogical composition of the material, the maximum admissible values for limonite iron ore and the minimum value for magnetite iron ore concentrate.

The experimental plant for introducing dustinto the blast furnace is shown in Figure 3. The installation consists of the following components:

- compressed air supply circuit (A);

- powder distributor (B);

- pneumatic transport of the material (C).

Its operating principle is as follows: compressed air brought to the distributor through the feed circuit, fluidization of the material and creating some overpressure, due to which the fluidized flow flows through the transport pipe to the tuyeres.

The flow rate is determined by the pressure difference and resistance on the fluidized bed transport path.

Figure 4 shows the portlance mounted on the nozzle of the blast furnace tuyere for introducing the combustion lance.

\section{Results and discussions}

To choose the most suited for use in the blast furnace mixt injection (iron ore, limestone and coke), the experimental researches have shown that they can be used the following comparison criteria for the iron ores ( $a, b, c$, d):

a -chemical composition (synthetic index: the iron percentage);

b -mineralogical composition and reductibility of iron ores (synthetic index: reductibility degree);

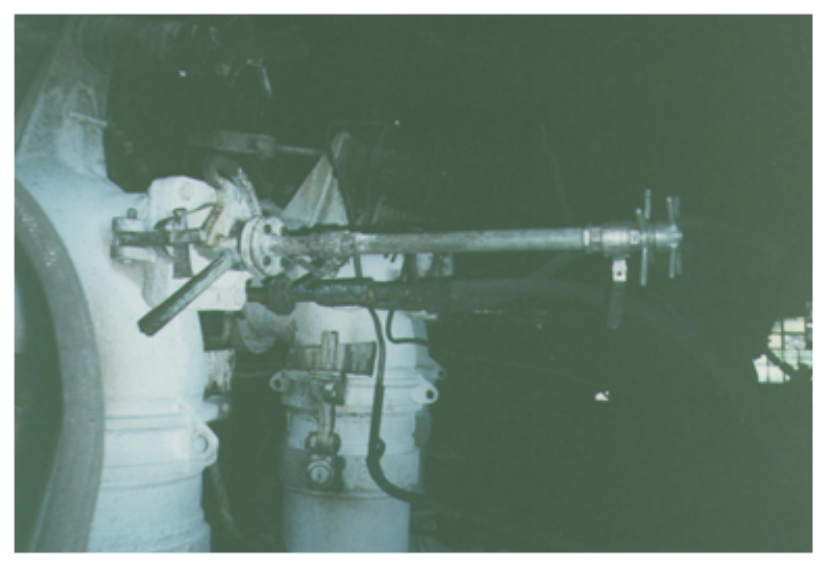

Fig. 4. Portlance mounted on the nozzle of the blast furnace [1]

C -granulometric composition and iron distribution in granulometric composition;

d -rheological characteristics (synthetic index: flow velocity);

As per these criteria, it was established that all iron ores and iron ores concentrate selected for analysis can be used for the mixt injection. Table 8 presents the classification made after the criteria above.

According to this classification, a relative superiority of the iron ore concentrates from Krivoi Rog and of the fine iron ores from India and Venezuela, can be observed.

In practical terms, each of the seven ferrous materials can be selected, depending on the supply options and the economic and financial aspects.

Due to their low content in fine fractions, below $0.1 \mathrm{~mm}$, and the inferior flow characteristics of the South Africa and Australia BHP iron ores, it is recommended to avoid using them in mixt injection.

Previous research has shown that the most reliable process, from a technic and economic point of view, for the injection of fine-grained materials in the blast furnace is the pneumatic transport in a dense state [5].

The pneumatic transport in the dense state is the technical solution, for pulverized coal injection, applied at blast furnaces from ARCELOR MITTAL GALATI.

This type of pneumatic transport is conditioned by the flow properties of the pow dered product to be transported.

Fluidizations characteristics of materials present importance, both in terms of dosage of materials, as well as in terms of transport in dense phase.

For comparison purpose with iron ores and limestone, have been studied and fluidization characteristics of the coal dust.

To bring them to the physical characteristics necessary for experimental researches, the materials went through prior preparation.

Preparation process included the following operations:

- crushing of materials to bring them to less than 0.1 $\mathrm{mm}$;

\begin{tabular}{|c|c|c|c|c|}
\hline \multirow{2}{*}{ No. } & \multicolumn{4}{|c|}{ Classification according with the criteria } \\
\cline { 2 - 5 } & a & b & c & d \\
\hline 1 & Venezuela & India & Krivoi Rog & Krivoi Rog \\
\hline 2 & Brazil & Robe River & Robe River & India \\
\hline 3 & South Africa & Venezuela & Brazil & Robe River \\
\hline 4 & Krivoi Rog & BHP & Venezuela & BHP \\
\hline 5 & India & South Africa & India & Venezuela \\
\hline 6 & BHP & Brazil & South Africa & Brazil \\
\hline 7 & Robe River & Krivoi Rog & BHP & South Africa \\
\hline
\end{tabular}

Table 8

STUDIED MATERIALS CLASSIFICATION [1] 
Table 9

PULVERIZED COAL/ORE/FLUX MIXING RECIPES, USED IN THE RESEARCH [1]

\begin{tabular}{|c|c|c|c|c|c|c|c|}
\hline \multirow[b]{2}{*}{ Recipe } & \multicolumn{7}{|c|}{ The proportion of each component } \\
\hline & Pulverized coal & $\begin{array}{l}\text { India iron } \\
\text { ore }\end{array}$ & $\begin{array}{c}\text { Brazll } \\
\text { concentrate }\end{array}$ & $\begin{array}{l}\text { Robe River } \\
\text { iron ore }\end{array}$ & $\begin{array}{l}\text { Venezuela } \\
\text { iron ore }\end{array}$ & $\begin{array}{l}\text { Krivoi Rog } \\
\text { concentrate }\end{array}$ & Limestone \\
\hline 1 & 2 & 3 & 4 & 5 & 6 & 7 & 8 \\
\hline A1.1 & 90 & 10 & - & - & - & - & - \\
\hline A1.2 & 70 & 30 & - & - & - & - & - \\
\hline A1.3 & 50 & 50 & - & - & - & - & - \\
\hline A2.1 & 90 & - & 10 & - & - & - & - \\
\hline A2.2 & 70 & - & 30 & - & - & - & - \\
\hline A2.3 & 50 & - & 50 & - & - & - & - \\
\hline A3.1 & 90 & - & - & 10 & - & - & - \\
\hline A3.2 & 70 & - & - & 30 & - & - & - \\
\hline$A 3.3$ & 50 & - & - & 50 & - & - & - \\
\hline A4.1 & 90 & - & - & - & 10 & - & - \\
\hline A4.2 & 70 & - & - & - & 30 & - & - \\
\hline A4.3 & 50 & - & - & - & 50 & - & - \\
\hline A5.1 & 90 & - & - & - & - & 10 & - \\
\hline A5.2 & 70 & - & - & - & - & 30 & - \\
\hline A5.3 & 50 & - & - & - & - & 50 & - \\
\hline B0.1 & 90 & - & - & - & - & - & 10 \\
\hline B1.1 & 80 & 10 & - & - & - & - & 10 \\
\hline B2.1 & 80 & - & 10 & - & - & - & 10 \\
\hline B3.1 & 80 & - & - & 10 & - & - & 10 \\
\hline B4.1 & 80 & - & - & - & 10 & - & 10 \\
\hline B5.1 & 80 & - & - & - & - & 10 & 10 \\
\hline
\end{tabular}

\begin{tabular}{|c|l|c|c|c|}
\hline \multirow{2}{*}{ No. Material } & \multicolumn{3}{c|}{ Behaviour } \\
\cline { 3 - 5 } & & Very good & Good & Satisfactory \\
\hline 1. & Brazil iron ore concentrate & $\mathrm{x}$ & - & - \\
\hline 2. & Venezuela iron ore & $\mathrm{x}$ & - & - \\
\hline 3. & India iron ore & $\mathrm{x}$ & - & - \\
\hline 4. & Krivoi Rog iron ore concentrate & - & - & $\mathrm{x}$ \\
\hline 5. & Australian Robe River iron ore & - & $\mathrm{x}$ & - \\
\hline 6. & Limestone & - & - & $\mathrm{x}$ \\
\hline 7. & Pulverized coal & - & $\mathrm{x}$ & - \\
\hline
\end{tabular}

Table 10

MATERIAL CLASSIFICATION BY THE BEHAVIOUR IN THE FLUIDIZED PROCESS
- granulometric separation to remove the oversized grains (over $0.1 \mathrm{~mm}$ );

- drying in the oven at $110^{\circ} \mathrm{C}$ to eliminate humidity.

Were prepared different mixing recipes according to Table 9.

The experiments were performed using a laboratory plant, consisting of a fluidizing reactor provided at the bottom with a removable grill sieve of $0.08 \mathrm{~mm}$. The grid serves as a support material layer and gas distribution layer.

As a fluidizing agent, it was used compressed air over the network.

At the beginning of each experiment, increasing gas velocity the dimension of material layers remains fixed, but there is an increase in pressure loss.

Starting at a certain speed the layers of the material is expanding. This value of gas velocity is called critical speed.

This state is the beginning of fluidization.

At gas velocity $>$ gas velocity critical speed, the expansion layer increases with increasing air velocity. This state called homogenous fluidization is characterized by small movements of granulation material.

In Krivoi Rog iron ore concentrate and pulverized coal, the homogeneous fluidization can be very intense, because of the phenomena occurring in the fluidized bed.

Because of these phenomena in the case of limestone and mixtures pulverized coal $+10 \%$ Krivoi Rog, respectively pulverized coal $+30 \%$ Krivoi Rog, could not observe a homogeneous fluidized bed.

In the case of limestone, there was observed a strong tendency to adhering to the walls of the fluidization reactor.
At higher gas velocity the layer tends to stir of increasingly intense.

In this turbulent fluidized state, the layer looks like a boiling liquid.

At higher gas speeds, the material layer passes into the pneumatic transport domain.

Attempts have shown that all materials are likely to be dense phase pneumatic conveying.

A hierarchy according to this criterion is presented in Table 10.

\section{Conclusions}

Experimental data obtained, permit the choice of materials most suitable for use in mixed injection technology in the blast furnace.

The results obtained are necessary to calculate the physical parameters of fluidization and pneumatic transport installations of mixt pow ders at the blast furnace.

Research has shown that the most convenient process from the technical and economical point of view to injecting fine granulation materials into the blast furnace, is densephase pneumatic transport.

When choosing the pneumatic transport solution, we also considered that at the furnaces from ARCELOR MITTAL GALATI are applied industrially the technological solution for the introduction of coal dust through the tuyeres.

Pneumatic transport of mixt pulverized coal, iron ore and limestone to the blast furnace tuyeres is an essential element in achieving mixt injection technology.

Chemically speaking, all ore and concentrates analyzed can be used to mixt injection in the blast furnace. 
It is appreciated that the development of a technology for introducing iron ore with limestone and coke through the tuyeres into the blast furnaces is technically and economically motivated and can be applied with minimum investment at ARCELOR MITTAL GALATI.

\section{References}

1. TUDOR, M.D., Studii sai cercetari privind stabilirea unei noi tehnologii de micoorare a consumurilor specifice de materiale si energie la producerea fontei de prima fuziune prin insuflarea combinata la furnal, Teza de doctorat, Bucuresti, 2013

2. CONSTANTIN, N., Ingineria producerii fontei în furnal, Editura Printech, Bucuresti, 2002

3. BUTNARIU, I., CONSTANTIN, N., DOBRESCU, C., HEPUT, T., Research on the Recycling of Pulverulent Waste from the Ferrous and NonFerrous Industry in Order to Reduce the Pollution, Rev. Chim. (Bucharest), 69, no. 5, 2018, p. 1066-1070,

4. SOCALICI, A.V., ARDELEAN, E., STRUGARIU, M.L., Research on sustainable use of powdery waste, Environmental engineering and management journal, Volume 15, Issue 1, p. 207-212, January, 2016

5. APOSTOL, C., BUTU, M., DOBRESCU, C., TACHE, A., Researches Regarding the Reduction of Oxidation Losses in the Obtaining of Secondary Aluminium Alloys Using Metallic Scraps,Rev. Chim. (Bucharest), 70, no. 1, 2019, p. 149-155
6. CONSTANTIN, C., TUDOR, M.D., DOBRESCU, C., CONSTANTIN, N., Fuel and energy consumption decrease to produce pig-iron for steelmaking using injection reducing gas in the blast furnace, J ournal of sustainable energy, Vol. II, nr. 2, 2011, p. 43-45

7. CONSTANTIN, N., STANASILA, C., STANASILA, O., DOBRESCU, C., GHEORGHE, N., PETRACHE, R., Finally ferrous waste recovery by conventional methods to obtain energy - technology conventional sources used as raw material in steel making, Metalurgia International, No. 3 special/nov. 2008, p. 17-21

8. VILCEA, E., Studii si cercetari experimentale privind eficientizarea elaborarii fontei de prima fuziune prin îmbunatatirea caracteristicilor fizico-chimice ale materiilor prime si micsorarea consumurilor specifice la furnal, Teza de doctorat, Bucuresti, 2013

9. SOCALICl, A.V., HEPUT, T., ARDELEAN, E., ARDELEAN, M., Ferrous waste processing by pelletizing, briquetting and mechanically mixed, International Journal of Energy and Environment, Volume 5, 2011, Issue 4

10. SOCALICI, A.V., ARDELEAN, E., CRISAN, E., Research on increasing the reaction surface of self-reducing briquettes, ENVIRONMENTAL ENGINEERING AND MANAGEMENT JOURNAL, volume 15, Issue 2, February 2016, pages: 443-451

Manuscript received: 1.10 .2019 